\title{
Godność osoby w szpitalnej piżamie. Wy-odrębnienie podstawą szacunku
}

„Szpitalna piżama"1 wydaje się frazą poruszającą, ponieważ dotyka naszego - wszakże dość powszechnego - doświadczenia; stawia przed oczyma sytuacje nasze i naszych najbliższych, gdzie owa „piżama” uosabiała specyfikę hospitalizacji i z nią związanych przeżyć. Jednym z nich bywa poczucie depersonalizacji, której sprzyja „rozebranie ze wszystkiego”, co na co dzień wyraża naszą rolę społeczną i rodzinną, niejako komunikując światu, kim jesteśmy, czym doniosłym się zajmujemy, „zapracowując sobie na uznanie". W osobie ubranej w piżamę trudno dostrzec (być może emerytowanego) nauczyciela, zabieganą babcię wnukom, ciężko pracującego pracownika budowy czy biznesmena. Nasuwa się refleksja, że niekiedy przydałoby się ubrać schorowane, leżące w szpitalu osoby w garnitury i krawaty, szykowne garsonki, prawnicze lub akademickie togi, aptekarskie kitle bądź inne emblematy ich społecznej aktywności i użyteczności, by choć w ten sposób uzyskać dla nich nieco więcej szacunku. „Ostatnia koszula człowieczeństwa"2 okazuje się bowiem niewystarczająca.

* Dr Małgorzata Wałejko jest adiunktem w Instytucie Pedagogiki Uniwersytetu Szczecińskiego, w Katedrze Teorii Wychowania. Adres: Instytut Pedagogiki USz, ul. Ogińskiego 16/17, 71-431 Szczecin; e-mail: malgorzata.walejko@usz.edu.pl.

${ }^{1}$ Formułę tytułu zawdzięczam panu dr. Bernardowi Sackowi.

2 Określenie autorstwa Etty Hilesum: Józef Augustyn, „Ostatnia koszula człowieczeństwa", Życie duchowe 31 (2002): 5-6. 
Można wytypować pewne grupy osób, wobec których postawa szacunku nie wydaje się oczywista w praktyce życia społecznego, by nie powiedzieć - zanika. W ich imieniu o szacunek musi upominać się pedagog. Są to dzieci, które, jak ubolewał Janusz Korczak, nie płaczą, lecz „mażą się i beczą" ${ }^{3}$, i wobec których nadal przez wielu usprawiedliwiana jest przemoc w majestacie pedagogiki (tzw. klaps).

Są to także osoby słabe i chore, często leżące, zdane na (nie)życzliwość innych. Nawet uwielbiani artyści, których naraz spotkał gorszy los. Anna Dymna zauważa: „Kiedy jesteśmy silni i zdrowi, to oklaskuje się nas, komplementuje, odbieramy nagrody. Aktor, muzyk, śpiewak operowy chory czy kontuzjowany jest po prostu wykluczony. Bywa, że nagle znika ze sceny i mało kto wie, co z nim się dzieje. Los moich kolegów, którzy chorują, staje się nieraz bardzo smutny"4. A zatem znikają ze społecznej świadomości schorowani, starsi, pozbawieni witalnych sił, by dowodzić swej wartości; ich rozum często nie działa sprawnie, upośledzając działanie woli - i to wystarczy, by tracili status osoby, co symbolicznie wyraża zaprzestanie zwracania się do nich kulturalnie i z dystansem poszanowania, tzn. per pan/pani, przez pracowników służby zdrowia lub socjalnych. Stają się „tatuśkami”, „dziadkami”, „babciami”, „kochanieńkimi”; „posuń się, przestań krzyczeć, cicho, czego chcesz".

Nieuprawniona stosowną zgodą osoby starszej forma zwracania się do niej na „ty” w tym przypadku wydaje się pozbawiać ją odrębności i niezależności. Osoby starsze bywają, z racji swojego osłabnięcia, zdane na pomoc innych. Nie bez powodu jednak wiele starzejących się osób panicznie boi się własnej bezradności; ona u tych jakkolwiek ,pomagających” często budzi przedziwne poczucie władzy i jej liczne demony. Traktują wówczas osoby starsze, $z$ tytułu ich zależności, jako podległe sobie, a fakt ich zależności wykorzystują niejako przeciwko nim, pozwalając sobie na lekceważenie albo i pogardę. Wtedy właśnie staje się jasne, czy zachowaniami moralnymi kierują powierzchownie „wytresowane” odruchy, czy autentyczne przejęcie się człowieczeństwem drugiego ${ }^{5}$.

${ }^{3}$ Zob. Janusz Korczak, Kiedy znów będę mały. Fragmenty utworów (Warszawa: Nasza Księgarnia, 1978), 181.

${ }^{4}$ Cyt. za: „Koncert charytatywny dla Marka Pacuły”, http://lovekrakow.pl/aktualnosci/ koncert-charytatywny-dla-marka-paculy_12772.html (dostęp: 2.02.2016).

${ }^{5}$ Zob. Wojciech Chudy, Pedagogia godności. Elementy etyki pedagogicznej, oprac. Anna Szudra (Lublin: Katolicki Uniwersytet Lubelski, 2009), 57-58. 
Myśl personalistyczna - niestrudzony rzecznik praw osoby we współczesnym świecie - odwołuje się do metafizycznych wyznaczników człowieczeństwa. Pragnę podjąć ów trop celem zaproponowania prostych sposobów przywracania osobom należnego im statusu w sytuacjach ruchowego ubezwłasnowolnienia, w placówkach szpitalnych lub domach opieki. Można bowiem zauważyć, iż wykład ontologicznych własności bytu osobowego wykazuje pełną aktualność, a nawet przydatność w praktyce społecznej pedagogiki.

Perspektywa personalizmu etycznego na tle „czysto” metafizycznego i liberalistycznego wydaje się o tyle adekwatna, iż dokonując syntezy metafizycznego wymiaru bycia osobą (jako ostatecznego wytłumaczenia osobowego bytowania, co skrzętnie w tekście praktykuję) i subiektywnej dostępności do bycia osobą na drodze doświadczenia, pozwala na przeżycie głębi i nienaruszalności osobowej godności wzniesionej na trwałym konstrukcie pryncypiów ontologicznych ${ }^{6}$.

\section{Odrębność bytowa jako podstawa godności}

Pod kategoriami konstytuującymi naturalny wymiar osoby dany w jej zewnętrznym oglądzie , istnieją pewne głębsze uwarunkowania zarówno istnienia, jak i osobowego charakteru każdej istoty ludzkiej", o których stanowi sfera metafizyczna ${ }^{7}$. Analizą metafizycznej struktury osoby ludzkiej zajmuje się nurt antropologii filozoficznej zwany personalizmem metafizycznym, interpretujący byt osobowy za pomocą przesłanek ontologicznych ${ }^{8}$. Tenże nurt, posiłkując się pojęciem substancji i substancjalności bytów (Arystoteles, a za nim św. Tomasz z Akwinu), wskazuje na osobę jako istniejącą samodzielnie, samoistnie. Cecha subsystencji jest samoistnością substancji, czyli istnieniem w sobie i przez siebie, nie zaś w innej rzeczy jako podmiocie 9 .

${ }^{6}$ Zob. Wojciech Chudy, „Oblicza personalizmu i ich konsekwencje”, Kwartalnik Filozoficzny 3 (1998): 80-81.

${ }^{7}$ Zob. Wojciech Chudy, Filozofia kłamstwa. Kłamstwo jako fenomen zła w świecie osób i społeczeństw (Warszawa: Oficyna Wydawnicza Volumen, 2004), 312, 319.

${ }^{8}$ Reprezentantami personalizmu metafizycznego są m.in. Jacques Maritain, Mieczysław Albert Krąpiec, Wincenty Granat.

9 Zob. Wincenty Granat, Osoba ludzka. Próba definicji (Sandomierz: Wydawnictwo Diecezjalne, 1961), 240; Mieczysław Albert Krąpiec, „Metafizyka - ogólna teoria rzeczywistości”, w: Piotr Jaroszyński, Stanisław Kamiński, Mieczysław Albert Krąpiec (i in.), Wprowadzenie do 
Dostrzeżona i doceniona już przez Boecjusza ,jednostkowość” jako cecha wy-osobnienia jednego bytu od drugiego implikuje istotne skutki dla rzeczywistości osoby. Dlatego konieczne jest odwoływanie się do pojęć tak abstrakcyjnych (jak subsystencja), by rzetelnie podjąć analizę rzeczywistości podmiotu. Właśnie ta metafizyczna właściwość sprawia, że suppositum „przewyższa głębią cały świat przedmiotów”. Jak pisze Jacques Maritain: „każdy z tych podmiotów w swojej odrębnej istniejącej rzeczywistości jest dla nas niewyczerpalną głębią poznawalności”. Jednostkowość umożliwia posiadanie istoty - tożsamości, bycie ,jakimś”. Oczywiście byty różnią się między sobą stopniem wewnętrznej złożoności, zintegrowaniem w indywidualności i jakością działań. Do najdoskonalszych należą obdarzone osobowym sposobem istnienia, wolnością woli: nie tylko bytują, lecz także działają (w znaczeniu działania świadomego, to jest czynu) samodzielnie ${ }^{10}$.

Wszakże z osobności krzeseł nic szczególnego nie wynika. Z osobności ludzi - tak. Osobowa subsystencja zakłada inne możności niż subsystencja nieosobowych substancji. W przypadku osoby subsystencja pociąga za sobą swoiście personologiczne atrybuty - z samodzielnym działaniem na czele. Czyn, wynik odrębności i rozumności, otwiera ludzką osobę na transcendencję, gdyż jako podmiot podejmujący samodzielne decyzje może on panować nad materią ${ }^{11}$.

Właśnie na osobowej odrębności nabudowane są władze duchowe osoby, które w aspekcie spełnienia i subiektywności osoby opisuje personalizm etyczny ${ }^{12}$. Pierwszą i zasadniczą władzą duchową osoby jest intelekt ludzki - umysł. Stanowi on najwłaściwszy przejaw „szczególnej pełni i doskonałości bytowania" (duchowości), która wraz z myśleniem pojęciowym odróżnia człowieka od bytów nieosobowych ${ }^{13}$. Umożliwia zarazem przeżycie osobowej podmiotowości. Intelekt przejawia się jak gdyby w dwóch wersjach: rozumu i woli.

Struktura ludzkiego poznania jest dwustronna: cielesno-duchowa. Mózg jest elementem pośredniczącym pomiędzy dwiema „stronami” poznania. Po-

filozofii (Lublin: Katolicki Uniwersytet Lubelski, 1996), 123-127,149-151; Marian Jaworski, Metafizyka (Kraków: W.I.T.K.M., 1998), 132-133.

10 Zob. Jacques Maritain, „Podmiotowość człowieka”, w: Jacques Maritain, Pisma filozoficzne, thum. Janina Fenrychowa (Kraków: Znak, 1988), 82, 84-85.

11 Zob. Granat, Osoba ludzka, 241-242.

${ }^{12}$ Reprezentantami personalizmu etycznego są Karol Wojtyła, Tadeusz Styczeń, Andrzej Szostek, Adam Rodziński, Wojciech Chudy. Tamże.

${ }^{13}$ Zob. Karol Wojtyła, Miłość i odpowiedzialność (Lublin: TN KUL, 1986), 24. 
rządki poznania są również dwa i odpowiadają wspomnianym ,stronom”: jest to poznanie zmysłowe i intelektualne. Jakkolwiek struktury poznawcze zmysłowe i intelektualne nie są tożsame, samo poznanie, analogicznie do jedności fizyczno-duchowej, jaką stanowi osoba, jest jednym procesem poznania. Rozum jest nośnikiem zdolności pojęciowania: tworzenia sądów i pojęć. Pojęcia są ogólne. Ich ogólność nie upośledza poznania: sprawia, że osoba w swym poznaniu dotyka bytu - ujmując go ogólnie, koniecznościowo i treściowo, zdolna jest transcendować jednostkowy sposób bytowania rzeczy ${ }^{14}$. Aktem rozumu jest prawda, stanowiąca wartość niezbędną dla realizacji osoby ${ }^{15}$.

Zachodzi więc ścisły związek władz duchowych z somatyką, gdyż niematerialne akty duchowe - władze działania duszy: ro zum i wola, działanie swe wyzwalają poprzez funkcjonowanie układu nerwowego ${ }^{16}$. Operacje umysłowe w wymiarze zewnętrznym są podległe czasowi przez wzgląd na materialność zmysłów i wyobraźni. Jednak same w sobie, jako duchowe, czasowi nie podlegają: ich ponadczasowe trwanie przypomina „niedoskonałe naśladownictwo wieczności” lub „następowanie po sobie kolejnych ułamków wieczności”. Stąd trwanie myśli, nie mieszcząc się w czasie, wykracza poza doczesność ${ }^{17}$.

Umysł jest źródłem wewnętrznego życia osoby, to jest życia duchowego, w którym poznawanie i pożądanie nacechowane jest zdolnością transcendencji. Centralną władzą duszy są akty woli ${ }^{18}$ uwarunkowane posiadaniem rozumu. Relacja pomiędzy rozumem a wolą jest kwestią dyskusyjną ${ }^{19}$, jednak nie ulega wątpliwości, że wola nie mogłaby istnieć bez istnienia intelektu; podobnie jak chcenie i wybór koniecznie poprzedzone są przez akt poznania. Właściwością osoby jest samostanowienie, natomiast urzeczywistnia się ono poprzez władzę (przypadłość) - wolę. „Samostanowienie stanowi istotę wolności człowieka"; wolność ta dokonuje się poprzez posiadanie woli ${ }^{20}$.

${ }_{14}$ Zob. Mieczysław Albert Krąpiec, „Kim jest człowiek?”, w: Piotr Jaroszyński, Stanisław Kamiński, Mieczysław Albert Krąpiec (i in.), Wprowadzenie do filozofii, 285-293.

15 Zob. Chudy, Pedagogia godności, 41.

16 Zob. Krąpiec, „Kim jest człowiek?”, 294.

17 Zob. Jacques Maritain, „Szósta droga”, w: Jacques Maritain, Pisma filozoficzne, 192-195.

18 Zob. Karol Wojtyła, „Osobowa struktura samostanowienia”, w: Karol Wojtyła, Osoba i czyn oraz inne studia antropologiczne (Lublin: Katolicki Uniwersytet Lubelski, 2000), 426.

19 Por. Granat, Osoba ludzka, 230-231.

20 Zob. Wojtyła, „Osobowa struktura”, 426-427. 
Jak widać z powyższych analiz, personalistyczna koncepcja podkreśla powiązanie cechy subsystencji (odrębnego bytowania) z podmiotowością osobową jako możliwą dzięki subsystencji. Odrębność bytowa, a wraz z nią odrębność intelektu i woli, przeżyć i wewnętrznego świata, a wreszcie godności, to podstawowa, konstytutywna cecha osoby z racji wymienionych implikacji, jakie niesie. To ciekawe, że jedną z boleśniejszych krzywd, jakie można człowiekowi wyrządzić, szczególnie dotkliwą niesprawiedliwością, jest próba pozbawienia go tejże odrębności, a poprzez to - statusu osobowego. Często dotyka to osób starszych.

\section{Choroba a status bytowy osoby ludzkiej}

Jakakolwiek ułomność, choroba czy stan braku przytomności nie dotyczą w sposób istotny struktury bytowej osoby ludzkiej. Wedle ustaleń metafizyki ogólnej żadna osoba nie jest niepełnosprawna bytowo, póki istnieje. Każdy byt bowiem składa się z części istotowych, integrujących oraz doskonałościowych. Pierwsze to elementy istnienia, istoty, formy i materii - jak ciało. Bez części istotowych rzeczywiście nie można istnieć i być osobą. Jednak uszczerbek w obszarze części integrujących (do których należą np. liczba kończyn, waga) i doskonałościowych (jak słuch czy inteligencja) jest immanentną cechą każdego, nie ma wszakże ludzi doskonale zintegrowanych materialnie lub doskonałych na przykład muzykalnie. Słabość jest zatem u jednych bardziej, a u innych mniej naoczna; są to jednak różnice zaledwie ilościowe ${ }^{21}$.

Koncepcja personalistyczna jest jedną z nielicznych uzasadniających niezmienną trwałość godności osobowej w przypadku osób, u których kierunkowe osobowe komponenty - rozum i wola - z różnych względów pozostają nieujawnione bądź ulegają zaburzeniu. Brak demonstracji funkcji czy cechy kojarzonych z człowieczeństwem nie oznacza zawieszenia człowieczeństwa, którego status metafizyczny pozostaje niezmienny.

Istotą swoistego optymizmu filozofii klasycznej w tym aspekcie jest

rozróżnienie między strukturą ontyczną osoby ludzkiej (np. duchem bądź jego «stronami»: intelektem i wolą), a funkcjami tej struktury (np. sprawnością umysłową). Zanik i zakłócenie funkcji i struktur osobowych wiążących się

${ }^{21}$ Zob. Wojciech Chudy, „Człowiek niepełnosprawny w świetle filozofii”, Ethos 3-4 (2007): 67-68. 
z istoty bytu ludzkiego ze sferami fizyczną i psychiczną, nie równa się unicestwieniu samych struktur. Fakt «zablokowania» dróg, którymi duch człowieka normalnie podąża ku swojej ekspresji (począwszy od narządu mowy, wzroku, a skończywszy na władzy rozumu) nie oznacza uszkodzenia czy degradacji samego ducha ${ }^{22}$.

Dla kochających osób czuwających u wezgłowia chorych, których władze poznawczo-wolitywne już dawno nie funkcjonują jak należy (po urazie, wskutek demencji, postępu choroby nowotworowej lub innych przyczyn), jest oczywiste, mocą swoistej ,intuicji miłości”, że owa dysfunkcja nie pozbawia osoby jej osobowej tożsamości i prawa do poszanowania. To nadal ta sama Mama, ten sam Tato, którego kocham - to ta sama osoba. Jednak podnoszenie kwestii trwałości statusu osoby mimo zakłócenia działania władz duchowych rozumu i woli jest o tyle zasadne, że mogący poszczycić się pełnią tychże władz szczęśliwcy nierzadko wykazują skłonność do dyskredytacji osobowego statusu tych, których rozum i wola funkcjonują nie w pełni lub doznają uszczerbku.

\section{Szanować - nie pozbawiać odrębności}

Szczególnie w postawach wobec osób jakkolwiek słabszych i bezradnych bezwzględnie konieczna jest komplementarność ich osobowej odrębności i wspólnotowości wyrażającej troskę i bliskość. Tu owa bliskość szczególnie - przez wzgląd na opisane na wstępie pokusy - musi pamiętać o respektowaniu tajemnicy odrębności osoby jakkolwiek ,ubezwłasnowolnionej”, w przeciwnym razie właśnie ta ,bliskość” w zdeformowanej postaci nachalnej i ckliwej dominacji będzie nastawać na osobową tożsamość starszego człowieka. W gerontopedagogice jednym z kluczowych jest postulat tworzenia z osobami w wieku poważnym wspólnoty opartej przede wszystkim na akcentowaniu ich permanentnej odrębności i niezawisłości, nawet jeśli w istotnym stopniu wydaje się ją ograniczać schorzenie. Potrzeba łączenia miłości ze szczególnym uwzględnieniem odrębności osoby starszej jest o tyle istotna, iż odrębność ta w imię źle pojętej opieki bywa zagrożona.

Swoiste ,pielęgnowanie” cechy własnej bytowej odrębności może być elementem samowychowania osób chorych, a jednocześnie powinno być podstawą odniesienia innych do osoby starszej.

22 Tamże, 68-69. 
Samowychowanie do świadomej odrębności osobowej to na przykład „uprawianie” własnego wnętrza, do którego zachęca Jan Szczepański, który za niekorzystne uznaje ciągłe obracanie się w świecie ludzi i rzeczy. Nakłania wszystkich do samotności celowej, jako postawy przyjaźni z własnym wewnętrznym życiem, czerpaniem z niego inspiracji, motywacji i preferencji aksjologicznych ${ }^{23}$. O ile nie ma materialnych (np. chorobowych) przeszkód w funkcjonowaniu intelektu i woli, właśnie te dwie władze, stanowiąc o ludzkiej odrębności, mogą być przedmiotem (auto)formacji osób starszych. W akcie swoistej samoobrony wobec tendencji pozbawienia osób starszych autonomii mogą one, w myśl wskazań Szczepańskiego, sięgać do podstawowego rysu ich osobowej autonomii - wewnętrznych władz poznania i woli, konstytuujących bycie osobą.

W sytuacjach unieruchomienia (przedłużającej się konieczności leżenia bądź niepełnosprawności) i odosobnienia (hospitalizacji) słuszna byłaby aplikacja psychologicznych technik ochrony normalnych funkcji umysłu, stworzonych dla ludzi postawionych w nieludzkich okolicznościach uwięzienia, izolacji i tortur ${ }^{24}$. Deprywacja sensoryczna - w tym głuchota, ślepota i osamotnienie, które niejednokrotnie dotykają osoby starsze - sprzyja utracie zdrowia psychicznego, generując lęki, fobie i halucynacje. Znane są jednak przypadki osób, które nawet rygorystyczne internowanie zniosły bez uszczerbku na psychice ${ }^{25}$.

Remedium okazuje się bogaty, zdyscyplinowany umysł oraz zachowanie własnego pola decyzyjnego, choćby wąskiego ${ }^{26}$, a zatem dbanie o zachowanie odrębności intelektu i woli. Warto zwrócić uwagę, że oba te atrybuty intelekt i wolę - to właśnie „najgłębszy nerw człowieczeństwa”27, własności duchowe o statusie osoby stanowiące. I o nie warto dbać w permanentnym samowychowaniu, szczególnie w sytuacjach zagrożeń naszej autonomii jak pisał Karol Wojtyła, „będąc osobą”, można wszakże - i należy! - stale się „osobą stawać”28.

23 Por. Jan Szczepański, Sprawy ludzkie (Warszawa: Czytelnik, 1978).

${ }^{24}$ Por. Christopher Burney, Solitary Confinement (Londyn: Non-Fiction Book Club, 1952).

${ }^{25}$ Zob. Anthony Storr, Samotność. Powrót do jaźni, tłum. Jerzy Prokopiuk, Przemysław J. Sieradzan (Warszawa: W.A.B., 2010), 83-85.

26 Zob. tamże, 84.

${ }^{27}$ Określenie autorstwa ks. abp. Wojciecha Polaka odniesione przez niego do cechy wolności.

${ }_{28}$ Zob. Karol Wojtyła, „Osoba i czyn”, w: Karol Wojtyła, Osoba i czyn oraz inne studia antropologiczne (Lublin: Katolicki Uniwersytet Lubelski, 2000), 144-145. 


\section{Docenienie odrębnego intelektu}

Pierwsze wskazanie to rozwój intelektualny, możliwy w każdych okolicznościach. Internowana na Węgrzech, przetrzymywana w ciemnej piwnicy dr Edith Bone, ponad sześćdziesięcioletnia lingwistka, recytowała i tłumaczyła w pamięci poezję, układała własne wiersze, ,skatalogowała” w pamięci pełny zasób słów w sześciu językach obcych, jakimi władała. Inne techniki to przechadzanie się w wyobraźni ulicami miast czy nucenie piosenek lub utworów muzyki klasycznej z pamięci. To wszystko ma na celu zachowanie aktywności umysłu, któremu nie są dostarczane zewnętrzne bodźce ${ }^{29}$. Analogicznie Ludwig van Beethoven mimo głuchoty komponował; co więcej, według jednego z biografów, głuchota miała pozytywny wpływ na potencjał twórczy Beethovena, gdyż wskutek wykluczenia doznań dźwiękowych mógł w pełni skupić się na kompozycji ${ }^{30}$. Sam stwierdził, że właśnie twórczość powstrzymała go od samobójstwa z rozpaczy ${ }^{31}$. Podobnie Goya - za sprawą głuchoty przestał malować portrety i zwrócił się ku innym formom sztuki, które jego zdaniem dawały większe pole inwencji i fantazji ${ }^{32}$. „Odcięty od wszystkich przez swą głuchotę, odkrył wrażliwość obserwatora, uświadomił sobie, że malarz musi jedynie prowadzić walkę z sobą samym, a także, iż prędzej czy później stanie się absolutnym zwycięzcą"33.

Cisza będąca synonimem samotności może zapraszać osobę starszą do „intelektualnej podróży”: „Cisza wypełniająca codzienność osoby starszej stwarza okazję do refleksji, szukania zrozumienia dla przeżywanych zdarzeń, odkrywania sensu starości. Jest to niejednokrotnie czas wewnętrznej przemiany, mającej swe źródło w pogłębionym życiu religijnym [...]" ${ }^{\prime 34}$. Intelektualna potencjalność powinna być więc potraktowana jako zadanie przez samą osobę starszą, ale i przez bliskie jej osoby, opiekujące się nią lub jej jakkolwiek towarzyszące. Przykładowo: podejmowanie dialogu jest poważ-

${ }^{29}$ Zob. Storr, Samotność, 83-85.

30 Zob. Maynard Solomon, Beethoven (Londyn: Littlehampton Book Services Ltd, 1978), 124 - cyt. za Storr, Samotność, 89-90.

31 Zob. Solomon, Beethoven, 117 - cyt. za Storr, Samotność, 89.

32 Zob. Storr, Samotność, 90.

${ }^{33}$ Andre Malraux, Saturn. An Essay on Goya (Londyn: Phaidon Publishers, 1957), 25 cyt. za Storr, Samotnośćc, 90.

${ }^{34}$ Katarzyna Uzar, Wychowanie w perspektywie starości. Personalistyczne podstawy geragogiki (Lublin: Katolicki Uniwersytet Lubelski, 2011), 35. 
nym potraktowaniem drugiej osoby, intelektualnym wyzwaniem i odpowiedzią na jej potrzebę komunikowania własnego Ja. Dialog przeciwstawia się także osamotnieniu.

\section{Docenienie odrębnej woli}

Drugie ze wskazań dla osób zagrożonych utratą poczucia tożsamości w sytuacji izolacji czy radykalnego osamotnienia to zachowanie jakiegokolwiek pola decyzyjnego. Anthony Storr zauważa: „Nawet więzień, który zdany jest całkowicie na łaskę lub niełaskę swoich ciemiężycieli, jest w stanie zachować pewien stopień autonomii. Może na przykład za każdym razem decydować, czy od razu zje podawany mu suchy chleb, czy też zachowa go na później. Od tego rodzaju pozornie trywialnych kwestii może zależeć, czy więzień zdoła zachować poczucie bycia odrębną jednostką"35. Podobnie Bruno Bettelheim akcentuje konieczność zachowania jakkolwiek małej sfery niezależności; jako więzień obozów koncentracyjnych zauważył, że „niemal wszyscy, którzy się tam poddali i zmarli, wcześniej wyzbyli się resztek osobistej autonomii, ulegli wysiłkom swoich prześladowców, mającym na celu dehumanizację i objęcie pełną kontrolą wszystkich aspektów ich życia"36.

Może dziwić zestawienie tak przerażających okoliczności sensorycznej deprywacji lub prześladowania z sytuacją chorych starych ludzi. Tymczasem w domach opieki niejednokrotnie można zaobserwować milczące, przedmiotowe traktowanie pensjonariuszy: karmieni bez rozmowy, posiłkiem, na którego formę nie mają wpływu, z zaangażowaniem uwagi równym przedmiotom nieożywionym. Brak dostrzeżenia w nich osoby z jej kluczowymi atrybutami intelektu i osobnej woli skutkuje tym, że sami stopniowo przestają w sobie odczuwać godność człowieczeństwa. Okazuje się, że proste i niewymagające wysiłku pytanie: ,czy ma Pan ochotę na deser? Czy może zje Pan później?” lub ,jaki owoc chciałby Pan zjeść?”, a może: „czy odpowiada Panu większa czy mniejsza poduszka?", uwydatniając osobową odrębność, może wyrażać szacunek dla osoby i - poprzez zatrzymanie się przed progiem jej tajemnicy i wolności - tworzyć afirmującą i sprawiedliwą wspólnotę.

Dowartościowanie niezawisłej woli, obok intelektu, jest nie tylko afirmujące i wspólnototwórcze w aspekcie odniesienia innych do osoby starszej. Świadomość woli może chronić także sam podmiot przed poczuciem deper-

35 Storr, Samotność, 84.

36 Tamże, 84-85. 
sonalizacji. Wszakże przeżycie ,jestem wolny” jest możliwe nawet w sytuacji opresji, upokorzenia czy „sytuacji bez wyjścia”; tak demonstruje się transcendentna natura osobowej wolności ${ }^{37}$. Wspomniany wcześniej Goya w wieku osiemdziesięciu lat, gdy nie słyszał i nie widział, powiedział: „Nie pozostało mi już nic oprócz woli - a tej mam w nadmiarze" 38 .

Wola dysponuje człowieka - o ile nie ma barier w funkcjonowaniu materialnej podstawy intelektu i woli - do wyboru wartości w każdej opresyjnej sytuacji, w jakiej się znajduje. To stanowi o swoistej osobotwórczej potędze ludzkiej woli wobec obiektywnych trudności (w tym i stopniowym „obumieraniu” funkcji rozumu), która ostatecznie rozstrzyga o spełnieniu i niespełnieniu człowieka jako osoby poprzez konsekwentny, potwierdzony czynem wybór aksjologiczny. Wszakże w myśl koncepcji personalizmu etycznego człowiek (aksjologicznie) nie spełnia się przez jakikolwiek czyn choćby tak spektakularny jak zdobycie Mont Blanc, wydanie bestsellera czy urodzenie pięciorga dzieci. Człowiek spełnia się przez czyn dobry moralnie, stanowiący zwrot ku prawdziwym wartościom: dobra i prawdy, wiary, nadziei i miłości. Możemy zatem mówić o spełnieniu osoby cierpiącej dojmujący ból osamotnienia w szpitalu czy domu opieki, ból fizyczny powodowany chorobą, a z nimi i smutek. W moralnych postawach osób stojących wobec życiowych prób przebija wyrazista, nieutracalna tożsamość zachowanej osobowej odrębności. Spełnienie osobowe daje poczucie szczęścia, które jednak nie musi wyrażać się emotywnie - ale na przykład, jak pisał Tauler, ,pokojem w niepokoju”39. „Decyzje egzystencjalne”, wskazujące na horyzont życiowych wartości, zdaniem Josepha Ratzingera stanowią „najmocniejszą gwarancję trwałości poczucia tożsamości mimo zmieniających się okoliczności życia i naturalnej zmienności przygodnych właściwości osoby [...]”40. W dialog z osobami obłożnie chorymi warto włączać ów aksjologiczny horyzont, by uświadamiać im, jak doniosłe - niezmiennie - są ich wybory moralne, preferowane przez nich wartości i wierność im. One świadczą o ich wolności - nienaruszalnej przez chorobę lub niepełnosprawność.

37 Zob. Chudy, Pedagogia godności, 40-41.

${ }_{38}$ Zob. Kenneth Clark, The Romantic Rebellion (London: John Murray/Sotheby, 1973), 95 - cyt. za Storr, Samotność, 91.

39 Zob. Anna Gałdowa, „Problem tożsamości w życiu duchowym”, w: Jeśli Bóg jest... Ksiegga jubileuszowa na siedemdziesiąte urodziny Ojca Profesora Jana Andrzeja Kłoczowskiego $O P$, red. Joanna Barcik, Grzegorz Chrzanowski (Kraków: Instytut myśli Józefa Tischnera, 2007), 286.

40 Tamże, 277-278. 


\section{Odrębność osób pozbawionych świadomości}

Świadome odwoływanie się do rozumu i woli osoby zarówno przez nią samą, jak i przez osoby z nią przestające, mające na celu unaocznienie ich niezmiennej odrębności skutkującej wymogiem szacunku, jest możliwe, dopóki władze te funkcjonują. Jednak specyficzna dialektyka odrębności chorego i bliskości z nim naznacza także ten okres życia osoby, gdy jej bytowa godność nie demonstruje się już naocznie, na przykład autonomią duchowych władz.

Skoro w przypadku starszej, chorej osoby zachowującej świadomość jest możliwe, by innym „mieszała się z tłem”, tracąc w ich oczach rys indywidualności, o ileż bardziej domaga się ocalenia tożsamość i wyakcentowania odrębność osobowa tych, którzy nie są w mocy w żadnej mierze dowodzić swego osobowego statusu, gdyż są pozbawieni świadomości.

„Ci dotkliwie drudzy, niedotykalnie drodzy” - pisze Stanisław Barań$\mathrm{czak}^{41}$, a wyrażona lapidarnie przezeń prawda zdaje się szczególnie dochodzić do głosu, gdy pozostaje nam być blisko, choć bliskość wydaje się niemożliwa; gdy budujemy wspólnotę z osobą, która nie mówi, nie słyszy lub nie reaguje.

Tworzona z nią wspólnota jest specyficzna, ponieważ naznaczona większą niż w przypadku relacji dwóch świadomości niekomunikowalnością, stanowi wspólnotę dwóch samotności. Wspólnotę konstytuuje tutaj sama obecność dwóch podmiotów, aż i tylko ona. Jest się „obecnym przy kimś”, choć w istocie to spotkanie dwóch obecności jakby „przedzielonych nicością”, bardzo w tym spotkaniu sobie odległych.

Obecność może być jednak wystarczającym komponentem wspólnoty. Dewiza etycznego personalizmu sformułowana przez Karola Wojtyłę, mówiąca, że osoba jest takim dobrem, iż jedynym właściwym odniesieniem do niej jest miłość, wskazuje na obecność osoby jako jedyny tytuł (warunek) dla tworzenia z nią wspólnoty - która staje się właśnie wspólnotą „odwzajemnionej obecności”. Prof. Janet E. Smith, etyk z Detroit, napisała:

Niektórzy mówią, że osoby w stanie wegetatywnym „nic nie mogą robić”. A le one mogą BYĆ i to proste BYCIE jest w istocie czymś; osoby w takim stanie lub w głębokiej demencji nie wydają się świadome [...].

${ }^{41}$ Fragment wiersza Stanisława Barańczaka „Płakała w nocy, ale nie jej płacz go zbudził”, w: Stanisław Barańczak, Chirurgiczna precyzja (Kraków: Wydawnictwo a5, 1998), 59. 
Jednak nie wiemy, co dzieje się w ich wnętrzu. Wiemy natomiast, że służą nam darem dla nas zbawiennym - mogą być obiektem naszej miłości, mogą przyjmować naszą miłość. I choć nie wiemy, jaki cud nasza miłość może w nich czynić, możemy mieć pewność, że ona dobro czyni w nas. Przecież noworodki też „nic nie mogą robić”, a są tak kochane i pieszczone - owszem, mamy nadzieję, że urosną i odwzajemnią miłość. Ale czyż nie kochamy ich BO SĄ? ${ }^{42}$

Analogiczne spostrzeżenia poczynił prof. Tadeusz Gadacz, odwołując się do osobistego doświadczenia straty małego dziecka. Zauważa, ,jak wielkim darem może być obecność bliskiej, kochanej osoby, każdy dzień i każda chwila tej obecności, każdy uścisk palca, każde dotknięcie"43.

Odrębność osób pozbawionych świadomości ma charakter ambiwalentny: $\mathrm{z}$ jednej strony wyrasta ponad inne atrybuty, gdyż drogi człowiek staje się tak osobny, tak daleki i „nieosiągalny”, jak nigdy wcześniej. Jak pisała Smith: nie mamy pojęcia, co dzieje się w jego wnętrzu. Z drugiej strony brak sprawczości i samostanowienia, absolutne zdanie się na opiekę osób trzecich sugeruje zanik odrębności aż po skrajne uzależnienie. Ostatecznie jednak sama odrębna obecność osoby, która żyje swoim, tajemnym i nietykalnym dla nas życiem, żyje niezmiennie tak samo, jak żyła wcześniej, korzystając $z$ konta i telefonu, jest wystarczającym tytułem, by o nią tak samo jak wcześniej dbać i ją szanować. Owa odrębna obecność osoby nieprzytomnej jest jej „ostatnią koszulą człowieczeństwa” - niestrojną i niemedialną - jednak odsłaniającą sam nerw, samą istotę bycia osobą: osobowe istnienie, osobowe aż po sam jego kres.

\section{$* * *$}

Według pewnej opowieści mężczyzna w podeszłym wieku odwiedzał $\mathrm{w}$ domu opieki swoją pogrążoną $\mathrm{w}$ demencji żonę. Pielęgniarki dziwiły się, że mimo własnej słabości przychodzi codziennie, by ją karmić. „Przecież ona nawet nie wie, kim pan jest” - tłumaczyły. „Ale ja wiem, kim ona jest” odpowiadał. Per analogiam, personalistyczna perspektywa „wie kim jest” każda osoba, której osobowe atrybuty pozostają uśpione. Jedynym adekwatnym odniesieniem wobec każdej osoby jest szacunek i miłość - niekiedy bardzo samotne - wyrażające się nade wszystko uznaniem odrębności osoby, która z racji bezradności wydaje się odrębność zatracać.

42 Janet Smith, "We feed roses, don't we? Further thoughts on passing of Terri Schiavo", Mosaic. A magazine for friends of Sacred Heart Major Seminary, Jesień (2005).

43 Tadeusz Gadacz, „List do Jacka Hołówki”, Znak 7 (2001): 20-22. 


\section{Dignity of a Person in Hospital Pyjamas. Individual Approach as a Basis for Respect (Summary)}

The text is a pedagogical response to depersonalization of people in a serious clinical state, elderly and/or chronically ill, frequently severely ill, staying in hospitals or total care facilities. Specific nature of hospital conditions ('pyjamas'), addressing a patient in the second person singular, refraining from a dialogue and depriving patients of the possibility to make basic choices contribute to isolation among patients and the feeling of losing their centrality. While referring to major metaphysical qualities of a personal being, the author marks possible ways of saving the sense of individualism among people who depend on care provided by others, which is the intellectual and volitional (self-)education. In the case of people who remain unconscious, an adequate and personalistic attitude involves building a community based on presence of two entities as a sufficient condition to develop a relationship in the meaning of the personalistic norm.

Tłum. Pawet Zimecki

Keywords: ontic separateness; dignity; senescence; personalism; disease.

\section{Godność osoby w szpitalnej piżamie. Wy-odrębnienie podstawą szacunku (Streszczenie)}

Tekst stanowi pedagogiczną reakcję na przejawy depersonalizacji osób w poważnym stanie klinicznym, starszych i/lub schorowanych, nierzadko w stanie obłożnym, znajdujących się w szpitalach lub placówkach opieki całkowitej. Specyfika warunków szpitalnych (,piżama”), zwracanie się per „ty”, niepodejmowanie dialogu i pozbawianie możliwości wyboru w elementarnych kwestiach sprzyja pogłębianiu osamotnienia podopiecznych oraz poczuciu zatracania osobowej podmiotowości. Poprzez odwołanie do kierunkowych cech metafizycznych bytu osobowego autorka sygnalizuje możliwe sposoby ocalenia poczucia bytowej odrębności osób zależnych od opieki innych - (samo)wychowanie intelektualne i wolitywne. W odniesieniu do osób nieprzytomnych adekwatną, personalistyczną postawą jest budowanie wspólnoty opartej na samej obecności dwojga podmiotów jako wystarczającym warunku tworzenia relacji w myśl normy personalistycznej.

Słowa kluczowe: odrębność bytowa; godność; starość; personalizm; choroba. 


\section{Bibliografia}

Augustyn, Józef. „Ostatnia koszula człowieczeństwa”, Życie duchowe 31 (2002): 4-6.

Barańczak, Stanisław. „Płakała w nocy, ale nie jej płacz go zbudził”. W: Stanisław Barańczak, Chirurgiczna precyzja, 59. Kraków: wydawnictwo a5, 1998.

Burney, Christopher. Solitary Confinement. London: Non-Fiction Book Club, 1952.

Chudy, Wojciech. „Człowiek niepełnosprawny w świetle filozofii”. Ethos 3-4 (2007): $67-80$.

Chudy, Wojciech. Filozofia kłamstwa. Kłamstwo jako fenomen zła w świecie osób i społeczeństw. Warszawa: Oficyna Wydawnicza Volumen, 2004.

Chudy, Wojciech. „Oblicza personalizmu i ich konsekwencje”. Kwartalnik Filozoficzny 3 (1998): 63-81.

Chudy, Wojciech. Pedagogia godności. Elementy etyki pedagogicznej, oprac. Anna Szudra. Lublin: Katolicki Uniwersytet Lubelski, 2009.

Clark, Kenneth. The Romantic Rebellion. London: John Murray/Sotheby, 1973.

Gadacz, Tadeusz. „List do Jacka Hołówki”. Znak 7 (2001): 20-22.

Gałdowa, Anna. „Problem tożsamości w życiu duchowym”. W: Jeśli Bóg jest... Księga jubileuszowa na siedemdziesiate urodziny Ojca Profesora Jana Andrzeja Kłoczowskiego OP, red. Joanna Barcik, Grzegorz Chrzanowski, 277-287. Kraków: Instytut myśli Józefa Tischnera, 2007.

Granat, Wincenty. Osoba ludzka. Próba definicji. Sandomierz: Wydawnictwo Diecezjalne, 1961.

Jaworski, Marian. Metafizyka. Kraków: W.I.T.K.M, 1998.

Koncert charytatywny dla Marka Paculy. http://lovekrakow.pl/aktualnosci/koncert-charytatywny-dla-marka-paculy_12772.html (dostęp: 2.02.2016).

Korczak, Janusz. Kiedy znów będę maty. Fragmenty utworów. Warszawa: Nasza Księgarnia, 1978.

Krąpiec, Mieczysław A. „Kim jest człowiek?”. W: Piotr Jaroszyński, Stanisław Kamiński, Mieczysław Albert Krąpiec (i in.)., Wprowadzenie do filozofii, 269-334. Lublin: Katolicki Uniwersytet Lubelski, 1996.

Krąpiec, Mieczysław A. „Metafizyka - ogólna teoria rzeczywistości”. W: Piotr Jaroszyński, Stanisław Kamiński, Mieczysław Albert Krąpiec (i in.)., Wprowadzenie do filozofii, 89-228. Lublin: Katolicki Uniwersytet Lubelski, 1996.

Malraux, André. Saturn. An Essay on Goya. London: Phaidon Publishers, 1957.

Maritain, Jacques. „Podmiotowość człowieka”. W: Jacques Maritain, Pisma filozoficzne, thum. Janina Fenrychowa, 81-98. Kraków: Znak, 1988. 
Maritain, Jacques. „Szósta droga”. W: Jacques Maritain, Pisma filozoficzne, thum. Janina Fenrychowa, 189-196. Kraków: Znak, 1988.

Smith, Janet E. „We feed roses, don't we? Further thoughts on passing of Terri Schiavo". Mosaic. A magazine for friends of Sacred Heart Major Seminary, Jesień (2005).

Solomon, Maynard. Beethoven. London: Littlehampton Book Services Ltd, 1978.

Storr, Anthony. Samotność. Powrót do jaźni, tłum. Jerzy Prokopiuk, Przemysław J. Sieradzan. Warszawa: W.A.B., 2010.

Szczepański, Jan. Sprawy ludzkie. Warszawa: Czytelnik, 1978.

Uzar, Katarzyna. Wychowanie w perspektywie starości. Personalistyczne podstawy geragogiki. Lublin: Katolicki Uniwersytet Lubelski, 2011.

Wojtyła, Karol. Miłość i odpowiedzialność. Lublin: TN KUL, 1986.

Wojtyła, Karol. „Osoba i czyn”. W: Karol Wojtyła, Osoba i czyn oraz inne studia antropologiczne, 43-344. Lublin: Katolicki Uniwersytet Lubelski, 2000.

Wojtyła, Karol. „Osobowa struktura samostanowienia”. W: Karol Wojtyła, Osoba i czyn oraz inne studia antropologiczne, 421-432. Lublin: Katolicki Uniwersytet Lubelski, 2000. 